\title{
Towards the marketization of early childhood education and care? Recent developments in Sweden and the United Kingdom
}

\author{
Ingela Naumann \\ School of Social and Political Science \\ University of Edinburgh \\ Email: ingela.naumann@ed.ac.uk
}

\begin{abstract}
Extensive public debate is being waged across mature welfare states as to whether social services are best provided by the state or the market. This article examines developments in Early Childhood Education and Care (ECEC) policy in Sweden and the United Kingdom, identifying trends towards marketization and universalization of ECEC that suggest a complex picture of competing policy logics and goals in the restructuring of welfare states. This article first discusses two models of early-years provision, the market model, and the universal model, outlining underlying assumptions, tensions, and implications of market and state provision of ECEC. A comparison of recent reforms in Sweden and the UK highlights how similar ideas and trends play out differently in different national contexts. In Sweden an integrated public 'educare' programme gradually developed over time, and market mechanisms introduced in the 1990s have so far had limited effect on the system overall. In the UK ideas about universal early childhood education became influential as part of a new social-investment agenda in the 1990s but have, owing to their restricted implementation, not fundamentally altered the existing childcare market. Historical policy trajectories continue to matter, yet tensions and incoherencies between policies can open spaces for change.
\end{abstract}

Keywords: Early childhood education and care, marketization, universalism, Sweden, United Kingdom, social investment

\section{Introduction}

The strengthening of economic principles in the organization and delivery of social services has been a recurrent theme in recent public-sector reform throughout mature welfare states (Pollitt \& Bouckaert, 2000). This article examines changes in Early Childhood Education and Care (ECEC) policy in Sweden and the United Kingdom since the 1990s, and asks to what extent these developments reflect general trends of marketization. Sweden and the UK are commonly characterized as 'universalist' and 'residual' welfare states, 
respectively, which reflects their markedly different welfare-state designs (see e.g., Sainsbury, 1991; Wincott, 2006). The generous public ECEC system in Sweden and the historical marginalization of childcare policy in the UK fit the picture well. Comparing developments around ECEC in these two contrasting cases helps highlight how similar trends and ideas play out differently in different national contexts. In both countries the marketization of early-years services has taken place with competition and for-profit provision playing a new or enhanced role. However, this is not the only trend in ECEC reform: in the same period public responsibility for and universal access to early-years services have been extended.

Such state-led service expansion may seem surprising in a general climate of financial austerity and retrenchment, and stands in tension with the neo-liberal underpinnings of the ideas of New Public Management that have influenced both countries (Blomqvist, 2004; Naumann \& Crouch, forthcoming). A number of scholars have linked developments around ECEC to the broader restructuring of welfare states towards a new 'paradigm' of 'social investment' (Taylor-Gooby, 2008; Jenson \& Saint-Martin, 2006). In this concept, earlyyears services play a central role in making parents and children productive workers in the present and future, which implies increased state involvement as a means for ultimately economic ends. It is important to note, however, that the various policy initiatives around ECEC in recent years cannot all be reduced to economic intentions. The trends of marketization and universalization in ECEC services do not add up to a coherent new welfarestate design, but present a contradictory mixture of policy goals and solutions. By disentangling the various developments around ECEC, this article suggests that, rather than a move from an 'old' towards a 'new' welfare state, what we may be witnessing is the maturation of 'old' policies alongside the pursuit of new agendas. Recent ECEC reforms in Sweden and the UK indicate some change in policy principles, while remaining enmeshed in the historical policy legacies of each country.

The first part of the article provides an analytical discussion of two contrasting approaches to ECEC services - the market model and the universal model as a framework for understanding the tensions and contradictions underlying ECEC reform. Thereafter, developments in ECEC policy in Sweden and the UK are examined. First, the two post-war ECEC systems are briefly outlined to help identify continuity and change in ECEC policy since the 1990s in the analysis that follows. The subsequent comparative discussion highlights tensions inherent in different reforms and the extent to which they have altered the pattern of national ECEC provision. The last section draws some lessons from the comparison of ECEC reforms with respect to welfare-state change in general.

\section{Competing models of early-years provision}

Recent academic debate about welfare-state reform in Sweden has revolved around the question of whether the introduction of market mechanisms in social services has led to the abandoning of universalism as guiding principle of the Swedish welfare regime (Blomqvist, 2004; Bergh, 2004). In the British case marketization trends are seen to be more in line with the traditionally restrained and targeted nature of state involvement in people's welfare in this 'liberal' or 'residual' welfare state (Wincott, 2006). Here, new commitments to universal provision, such as in preschool education, have been dubbed a 'quiet revolution' (Smith, 2007). It is noteworthy, however, that the principle of universalism has always been part of the Beveridgean post-WWII welfare 
state, for example, in National Health Insurance or the national pension. Such observations invite a focus on the dimensions of 'selectivity' and 'universalism' when assessing changes in ECEC policy in Sweden and the UK. The discussion about 'market' versus 'state' in social-service delivery can be cast within these specific dimensions. However, this debate also has broader scope, because it considers not only the type of policy instruments chosen and level of generosity, but also different perspectives on the types of relations social services do, or should, entail.

\section{The market model}

The ECEC market is constituted by the exchange relationship between individual purchasers (parents) and private, commercial providers (firms or corporations). Both purchasers and providers are assumed to behave as selfinterested actors: parents by seeking the best ECEC solutions and providers by seeking profit-maximization. The 'pure' childcare market is also assumed to be self-regulatory: the size of the childcare sector, the available types of services, the prices and the quality will reflect demand; consumer choice and competition produce an incentivizing mechanism in that providers offering unsatisfactory services will be squeezed out of the market. The expected outcome is an ECEC sector that both displays a high degree of diversity, which reflects parents' differing preferences, and delivers high-quality, costeffective ECEC services.

The appeal of the market model to pressure groups (parents) and policymakers lies in its responsiveness to consumers and its promises of efficiency. It also allows governments to refrain from explicit normative decisions about who should be using ECEC services because the market is supposed to be demand-driven. ${ }^{1} \mathrm{~A}$ core assumption on which the market is premised is that 'buyers' are well-informed about the 'product' they purchase and are free to enter or exit a transaction. In practice, however, there are various constraints on parental choice, constraints which are implicated in dysfunctional market developments (see also Ball \& Vincent, 2005). First, since the cost of ECEC services is borne by the parent-purchasers, access to services is determined by parents' resources. Some parents will be unable to afford ECEC services altogether, and others will have to content themselves with inadequate solutions. Secondly, parents tend to be logistically and geographically constrained. Since commercial providers are likely to target buyers with the highest purchasing power, geographical service imbalances may be the result, with good and varied availability in affluent urban areas and scarce or unsatisfactory provision in disadvantaged or remote areas. 'Need' foremost parents' need for childcare in order to hold down a job - is the most immediate limitation to 'free choice'. If the need is strong, providers may become less responsive to demands and expectations, and might, for example, trade quality for efficiency because they will get their customers anyway. Lastly, not all parents hold the necessary expert knowledge that enables them to assess the suitability and quality of early-years services. The ECEC market can, therefore, be seen as being highly selective, where affordability, availability, and the advertisement power of firms directly influence parental choice, and in practice these factors leave many with little choice at all.

\footnotetext{
${ }^{1}$ While the market model is grounded in normative assumptions about social relations, public debate has tended to focus on its instrumental aspects. This is beneficial for governments since the declining stability in voter-alignments have made value statements politically more risky.
} 
No such 'pure' ECEC market seems to exist anywhere. No welfare state dares to leave the provision of early-years services fully to market forces because children are considered a particularly vulnerable group in society in need of special protection. Thus, even in countries such as the US or the UK, where 'childcare markets' are said to exist, these are in fact strongly state-regulated (Penn 2010). Secondly, children are not only the 'private pleasure' of their parents but carry certain 'public-good' characteristics. Welfare states have always had an interest in influencing the 'quantity' and 'quality' of the future generation of citizens, workers, and soldiers via a range of social policies (see e.g., Myrdal, 1945; SOU, 1972; HMT, 2001). In some countries such as France and Sweden, the potential of early-years services to impact on children's health and socialization, as well as on family and fertility behaviour, has received attention already in the early twentieth century (Naumann, 2006); in other countries such as the UK this focus has more recent origins (Lloyd, 2008; Smith, 2007). Broader goals such as poverty alleviation or the reconciliation of family and work cannot easily be achieved through the market owing to its selection effects, and this difficulty has led states to intervene in ECEC provision. Thirdly, the increasing recognition of young children's right to educational opportunities, as reflected in Article 28 of the UN convention of the Rights of the Child (UNCRC), has galvanized governmental action (UN, 1989). For these reasons, welfare states are involved in the regulation, funding, and provision of early-years' services, albeit to varying degrees. In some countries such as Sweden, state involvement in ECEC has approached a 'universal model', as outlined below.

\section{The universal model}

In the universal model, provision and funding of all ECEC services are public. ECEC in this model is understood as a social right - a right that extends to both parents and children as actual users of ECEC services ${ }^{2}-$ meaning that access is open to all children irrespective of socio-economic background and, in a pure model, free at point of delivery (see also Bergh, 2004). The socialrights character implies that social risks associated with the early years - such as parents' need for extra-familial childcare, children's special or general needs for good care, and learning environments - are covered collectively via citizens' tax contributions. The public responsibility for ECEC in turn implies a public interest, and public interest thus entails public debate over the content and aims of ECEC services, which connects with broader societal goals that are most likely guided by dominant cultural norms.

The appeal of this model to pressure groups (children's advocates, educational specialists, women's movements) is its emphasis on citizenship, that is, the manner in which ECEC extends to wider society and can be claimed as inalienable right. Its appeal to governments is state control and its integrative potential. The possibility of pursuing broader goals through ECEC services directly influence the behaviour of families and foster social cohesion. But the universal model also has shortcomings because the principle of universalism may produce highly standardized services to ensure equal access and availability across a country. In 'real-world' contexts this may imply an unsatisfactory fit between available services and local or individual needs. The focus on children and their rights implies an obligation to certain quality standards of service provision. Depending on how 'quality' is socially defined

\footnotetext{
${ }^{2}$ In the market model the children's position is more ambivalent. While they are users of ECEC services, they are also the 'product' of the transaction between parents and service providers. Further, the main focus in the market model rests on parents as service-purchasers.
} 
this can be very costly for welfare states. Under conditions of economic constraint, tensions may arise between 'universal access' and 'quality' where the latter may be traded for the former. Furthermore, by reproducing dominant norms and ideals about children and social relations (e.g., about gender roles) in the types of services offered, certain understandings and forms of ECEC will be marginalized or excluded. There is thus an inbuilt tension in the universal model between universalism and citizen's individual needs and preferences, a tension that has intensified over last decades as advanced societies have become more pluralist and diverse.

To sum up, both the 'market model' and the 'universal model' of ECEC provision carry theoretical appeal while also leading to inadequacies in practice. The market is expected to produce responsive, diverse, and efficient ECEC services, but is highly selective; the universal system is expected to provide equal access and opportunities for all children, yet may become uniform and unresponsive. 'Quality' of services can in practice become a problem with both models. When examining recent national ECEC reforms we should thus not expect unidirectional developments towards either market or state provision, but policy responses that attempt to cater to an array of goals by combining diverse policy instruments and logics.

An increased policy orientation towards the ECEC market model, termed 'marketization' in the discussion below, could happen along one or more of the following dimensions:

- A decrease in state regulation, such as the relaxation of inspection regimes or standardized quality requirements (e.g., staff-to-child ratios, health, and safety).

- A decrease in state funding and subsidies to suppliers or service users.

- A decline in the proportion of public or publicly funded services in favour of for-profit providers.

- The introduction of market mechanisms such as choice and competition, and a strengthened focus on efficiency and economic goals.

Not all developments of privatization necessarily imply marketization: independent charities and other non-profit organizations may also provide private services. Privatization is linked to marketization whenever it involves an increase in individual risk and costs to service users (i.e., reduction in state funding) and where non-profit providers are encouraged to act like firms.

The 'universalization' of ECEC means extended access to good-quality services independent of service users' socio-economic background. It can also include a strengthened framework for public funding and regulation and the recognition of public responsibility for children's upbringing. Yet not every increase in state involvement necessarily equals a development towards the universal model. Targeted measures are likely to underscore socioeconomically stratified access to services; differentiated parental fees, on the other hand, may support the principle of universalism. Nor does 'universal access' of itself imply programme generosity or comprehensiveness, even though these aspects are commonly associated with each other in characterizations of Nordic welfare states (Bergh, 2004), for it does not define the extent of membership. In practice universal ECEC policies may be of quite limited character, guaranteeing access only to certain age groups of children (e.g. three- to five-year-olds) and for certain times (e.g., part-time). 
There is thus no simple trade-off between market provision and universal ECEC - more 'market' does not necessarily mean less 'state' - and no linear relationship exists between the two. Rather, both models are outlined here to highlight the shaping of ECEC systems by different and competing logics and mechanisms: parental preferences versus citizenship; competition versus public planning; individual interests versus collective interest. The ways in which trends of 'marketization' and 'universalization' have manifested themselves in Swedish and British ECEC will be examined next.

\section{ECEC policy developments in Sweden and the UK}

\section{Historical Background}

During the post-WWII decades ECEC services were equally scarce in Sweden and the UK, the male breadwinner model was dominant in both countries, and small children were seen to be best cared for by their biological mother. In Sweden in 1968, two per cent of children aged four, 11 per cent of the fiveyear-olds, and 43 per cent of six-year-olds were in childcare and preschool programs (Naumann, 2006). In the UK in 1965, two per cent of three to fouryear-olds had access to state-provided childcare and 11 per cent of children had some kind of out-of-home care (Penn, 2009, p.117). ${ }^{3}$ In the following decades ECEC services in Sweden expanded dramatically on the basis of strong demand by working parents, radically changing social norms about gender roles and children's place in society, and a high welfare-state commitment. In the UK, on the other hand, state involvement in ECEC service provision remained minimal, where the raising of children was defined as a private family matter and the norm of the male breadwinner remained dominant.

\section{Sweden}

In Sweden, a unitary public ECEC system for children aged one to six was established in the early 1970s. Designed as a collective full-day service, modern Swedish ECEC was intended to fulfil a wide range of functions: to provide good-quality day care while also offering pedagogically sound learning spaces; to enhance gender equality by supporting the reconciliation of work and family life; to mitigate class differences by offering children equal educational opportunities from an early age; and to support economic growth and welfare-state sustainability by bringing as many parents as possible into the labour market. The foundations for this public ECEC system were laid in 1972 by an extensive state investigation that detailed major aspects of these services, drawing on psychological child development research, sociological, and economic theory, and by synthesizing political goals with feminist thinking on childcare that had been debated since the 1920s (SOU, 1972; Naumann, 2006). Universal availability of public ECEC grew to become a central political promise of the Swedish Social Democratic government (Naumann, 2006).

\footnotetext{
${ }^{3}$ Children in Britain normally enter school at the age of five, while their Swedish counterparts do so at the age of seven.
} 
The universalization of ECEC services in Sweden was a gradual process that took shape over several decades. In 1973 the state for the first time formalized its responsibility for ECEC by obliging municipalities to provide free earlyyears services to preschool children, albeit at that point only for six-year-olds. In 1976 a bill was passed with the ambitious plan to expand ECEC with 100 000 new day-care places and 50000 after-school places (Antman, 1996). In 1980 the provision of ECEC services was legally placed under municipal responsibility, but with substantial financial contributions by the central state. In 1985 a new expansion programme was passed with the aim to provide by 1991 ECEC for all children aged one-and-a-half to six years whose parents were gainfully employed (Antman, 1996). The state's financial commitment to its expansion plans was considerable: social expenditure for ECEC rose from 0.15 per cent in 1963-1964 to 2.75 per cent in 1987-1988 (Hinfors, 1990, p.49). Between 1975 and 1990 ECEC services expanded from a coverage of 17 per cent to 52 per cent of children aged one to six (Bergqvist \& Nyberg, 2001, p.243). Despite this massive expansion, the demand for places grew faster in line with women's mass-entry into the labour market; childcare queues were long, and places were generally reserved for children of working parents or for children with special needs (Naumann, 2006).

\section{United Kingdom}

In the UK ECEC services developed slowly in the absence of an explicit childcare policy in a mixed economy with an administrative bifurcation into care and nursery education. The Department of Health (DHSS) was responsible for childcare, mainly developing targeted programmes aimed at children at risk, and the Department for Education (DfEE) was in charge of preschool education. The implementation of programmes and the levels of day-care and nursery-school provision were left to local authorities (LAs), but limited financial support from central government meant that LAs' actions were restricted. During the 1970s the national government started to take greater interest in ECEC, especially in preschool education, and a gradual increase in public nursery schools took place. In 1972, the then education minister, Margaret Thatcher, announced expansion plans for preschools to provide sufficient places for all three- and four-year-olds according to demand by 1982. However, these plans were quickly scrapped when the Conservatives returned to power under Thatcher in 1979 (Randall, 2002). Owing to lack of available ECEC services and the growing need, parents started to organize play-groups and parent co-operatives, and private day care and childminding, both in registered and unregistered forms, expanded considerably (Penn, 2009).

Contrary to feminist pressure in the 1980 s to open the childcare system to all children, the Thatcher and Major governments focused on preschool education as part of a broader agenda to reform the educational system along the lines of marketization and centralization (Ruggie, 1984; Naumann/Crouch, forthcoming). Nursery schools did not have to be organized through the state educational system, but a new voucher scheme led many primary schools to set up 'reception classes' for four-year-olds to claim the voucher money (Penn, 2009, p.120). The government also initiated a series of 'Under-Fives Initiatives' in which it worked directly with voluntary providers, therewith bypassing the LAs (Randall, 2002, p.225). The responsibility for the organization of day care was left to LAs, mainly as a measure for families in need, and the 1989 Childcare Act set out an inspection and standards regime under which private childcare providers had to be registered and inspected at local governmental level. As a consequence of these policy developments, public childcare places remained very scarce for children under the age of 
three, with a coverage of two per cent in 1993, while (part-time) nursery schools for three- to four-year-olds expanded considerably to cover 60 per cent of this age group (Bahle \& Pfenning, 2001). Private ECEC services increased more than threefold, and ECEC service provision fragmented, resulting in considerable regional and local variations in the availability and the quality of services (Randall, 2002).

By the beginning of the 1990s Sweden had an extensive public ECEC system with a broad remit, while in the UK a mixed economy of ECEC services existed with a clear distinction between care and preschool education alongside an increasingly dominant role for private providers. Albeit with some delay, both ECEC systems had developed in line with the general welfarestate trajectories of the two countries: generous public-service provision in Sweden based on the principles of equality and universalism and the dualearner family norm; and limited state involvement in day care in the UK, reflecting a preference for means-testing and low de-commodification, along with an ambivalence towards mothers' employment characteristic of the British welfare state. Part-time preschool education had been recognized as desirable; however, at the same time as preschool services received more attention by the state, they became part of new marketization trends within the educational system. Since the 1990s changes have taken place in the Swedish and the British ECEC system that both strengthen and challenge these earlier developments.

\section{ECEC reforms in the 1990s and 2000s}

\section{Sweden}

Criticisms concerning the legitimacy and efficiency of large, uniform and centrally led public services had mounted during the 1970s and 1980s. These concerns, together with the spreading of New Public Management (NPM) ideas, led in the 1990s to the decentralization of public-sector governance and the opening up of the welfare system to private providers of every kind (with non-profit and for-profit orientations) (Blomqvist, 2004). In 1991 the newly elected centre-right government promised a 'choice revolution' that would increase diversity and economic efficiency in public services. The old topdown, regulation-heavy relationship between the central state and municipalities was replaced by a system of governance by objectives for key social services, and detailed earmarked state funding to municipalities was replaced by block grants. Deregulation and decentralization gave the municipalities considerable freedom to decide over the organization and delivery of social services, including ECEC.

Until the 1990s, private ECEC services hardly existed beyond a few facilities with specific pedagogical traditions (e.g., Montessori, Rudolf Steiner) or facilities set up by parent co-operatives owing to a lack of available public childcare. In 1984 the Social Democrats passed a law prohibiting commercial childcare services in response to one large corporation's attempts to develop such nurseries. However, in 1991 the then conservative government removed most of the restrictions on the establishment of non-municipal, private ECEC services, and from 1992 onward even for-profit providers were given access to public funding (Strandbrink \& Pestoff, 2006, p.43). Following these developments, the number of non-municipal ECEC facilities increased from 500 in 1988 to 3113 in 2002, providing ten per cent of places for children aged one to six. The number of for-profit providers on all private facilities was low throughout the 1990s but increased during the 2000s; by 2008 the proportion 
of privately provided places had increased to 14.2 per cent (SOS, 2009). Today, for-profit ECEC makes up a bit less than ten per cent of Swedish ECEC places overall, but large differences exist between municipalities, with commercial ECEC being hardly existent in some whilst being widespread in others (Skolverket 2010).

In the mid-1990s, Sweden was hit by a severe economic crisis. Nevertheless, state funding of ECEC remained constant in this period: public expenditure for ECEC and after-school care was 3.78 billion euros in 1990, 3.67 in 1995, and 3.81 billion euros in 1997. However, the demand for childcare also rose sharply in the 1990s, leading to renewed massive service expansion, from around 330000 places in 1990 to over 700000 places in 2000. This expansion that took place without additional funding raised public concern about a potential reduction of quality of early-years services, as indicated in the deteriorating child-staff ratio from 4.4 in 1990 to 5.7 in 1998. However, this trend was reversed through earmarked state grants to increase staff numbers in preschools in the 2000s; in 2006 the staff-child ratio was 5.1 (Skolverket, 2008, p.39). It has also been noted that changes in quality are difficult to assess due to other developments (Bergqvist \& Nyberg, 2001). In the same period a professionalization of ECEC staff took place, with an increase in the proportion of staff holding university degrees, rising to 54 per cent in 2000 (Skolverket, 2000, p.49). Furthermore, service integration on the municipal level between school education, ECEC, and after-school care intensified in ways that allowed for more efficient use of resources, such as the sharing of facilities and activities (Cohen et al., 2004). In 1998 a preschool class for sixyear-olds was introduced as part of the school system, and consequently this age group was removed from the ECEC system's planning and costing. Many municipalities also responded to financial constraints by off-loading costs to parents. In 1990 parental fees covered ten per cent of total ECEC costs; by 1999 this figure had increased to 18 per cent (Bergqvist \& Nyberg, 2001, p.265).

These changes - decentralization, deregulation, and privatization - led to considerable differences between municipalities with respect to variety, availability, parental fees, and quality of ECEC services (Strandbrink \& Pestoff, 2006, p.44; Cohen et al. 2004). However, policy reforms implemented during the latter part of the 1990s and the early 2000s display attempts to reverse some of these developments, along with a renewed emphasis on universalism and a retrieval of central state control. The pedagogical focus of early-years services was strengthened by transferring the responsibility for these services from the Social Department to the Education Department. In 2001 a new system of integrated teacher training for school teachers, preschool, and after-school pedagogues further augmented the educational standing of preschool staff (Cohen et al., 2004). In 1998 a national curriculum for children aged one to five was introduced that not only outlined the pedagogical remit of early-years services (which is broader than the understanding of 'education' in the UK), but also pointed to their societal mission of transmitting democratic values and practices (Lpfö, 1998). Following this educational logic, in 1999 a statutory right to early childhood education was extended to all children, including children of unemployed and non-working parents. The 1999 bill obliged municipalities to provide a place for every child from one year of age within three months of application. In addition, preschool for four- to five-year-olds was made free of charge. And in 2000 the national government set upper limits to municipal parental fees, the so-called 'max tax', to ensure affordability for all parents: parental fees are differentiated according to income, but do not exceed three per cent of family income for the first child and two per cent for the second child (Skolverket, 
2007). By the beginning of 2000, the Swedish ECEC system had become fully universal. Today, almost half of one-year-olds, 91.3 per cent of two-year-olds and 97 per cent of three- to five-year-olds attend ECEC services (SOS, 2010).

\section{United Kingdom}

When the Labour Party came to power in 1997, it announced radical changes in the direction of childcare policy, committing itself to providing sufficient and affordable ECEC services. The then Chancellor of the Exchequer, Gordon Brown, declared in his budgetary speech that childcare would be an integral part of New Labour's economic policy, and in 1998 the government produced the first National Childcare Strategy (DfES, 1998). Its aims were to combat child poverty and social exclusion by bringing parents into paid work and supporting children's 'early learning'. Linking ECEC explicitly to the reconciliation of work and family life also meant a new direction in family policy because it promoted the dual-earner family (Lewis, 2003; Lloyd, 2008). In addition a 'Sure Start' programme was introduced in 1999 to provide public early-years services in disadvantaged neighbourhoods. Declaring the desirability of collective childcare was indeed a radical shift from previous governmental policy. But with the central focus on low-income parents and their children, the New Labour government remained committed to their Conservative predecessor's focus on reducing welfare dependency, albeit with a more active role for the state.

In its 2001 manifesto the Labour party promised to create 1.6 million new childcare places and in 2004 the government presented a Ten-Year Strategy (HMT, 2004) that set up an extensive policy framework for the development of ECEC services; it became formalized in the 2006 Childcare Act (applicable to England). With their expansion plans, New Labour continued and reinforced the trends of marketization in the ECEC sector that had taken place earlier. While the Childcare Act set out how local LAs were to assess, coordinate, and inspect public and private ECEC services, it also made explicit that LAs were only to provide services themselves if there were no private alternatives available (HMT, 2004). The government initiated various supply-side measures of 'pump priming' and start-up funding, which encouraged private providers to establish ECEC services, but it did not increase state funding for LAs to fulfil their obligations. State expenditure on ECEC increased moderately from a low 0.2 per cent of GDP in 1998-1999 to 0.4 per cent in 2003 (OECD, 2005, pp.109f.). A new system of Childcare Tax Credits was introduced to help working parents with childcare costs. These demand-side subsidies covered up to 80 per cent of childcare costs for low-income families, but quickly decreased with growing income to ten per cent or less for middleincome families. With these policies New Labour continued the commitment to restrict public-service provision and to strengthen parental choice and service plurality via market mechanisms.

However, other aspects of the Childcare Act and further initiatives in the 2000s did not follow this market logic but instead emphasized the importance of early-years provision for all children's education and well-being, placing these services in a wider community context. With the 2006 Act, the state for the first time announced its legal responsibility to provide ECEC. It obliged LAs to offer a free preschool place to every child aged 3-4 for 2.5 hours a day, as well as sufficient childcare and after-school care for children of all ages whose parents were at work or in training. A preschool curriculum for three- to four-year-olds was introduced, partly to improve educational standards in preschool settings, and in addition to integrate care and education, since the national curriculum 
was also intended for facilities offering day care for this age group. The creation of a new Department for Children, Schools, and Families responsible for all child- and family-related services further emphasized this more holistic view of the child that linked care, education, and wider aspects. In England the state-run Sure Start centres were expanded to become Children's Centres comprising, besides ECEC, a wide range of family and community services such as parenting classes, health care, citizen's advice, and employment bureaus. The Children's Centres were to be located primarily in disadvantaged areas, but were to expand gradually to every 'local community' in England (Ball \& Vincent, 2005; Lloyd, 2008).

Following these initiatives, ECEC services expanded considerably in the UK. In 200435 per cent of children aged zero to two years and 86 per cent threeto five-year-olds had an ECEC place (Plantenga et al., 2008, p.30); among four-year-olds there is today almost full coverage. The expansion of places for three-year-olds took place mainly in the private service sector, and, as a consequence, the proportion of publicly provided places decreased from 85 per cent in 2000 to 47 per cent in 2004 in England and Wales. The majority (81 per cent) of four-year-olds attended public settings, mainly through reception classes in primary schools (Brewer et al., 2005, p.166). Devolution in the UK at the end of the 1990s meant that ECEC services became the responsibility of the respective nations, and differences in policy orientation do exist, particularly between England and Scotland (Wincott, 2006; Cohen et al., 2004). From the standpoint of comparisons between countries, however, the similarities in the structure of the ECEC sector prevail, not least because important subsidies such as Tax Credits are operated by the central government.

New Labour have described their targeted approach as 'progressive universalism' (HMT, 2001) -a definition that is notably not based on ideas of public-service provision for all, irrespective of socio-economic background. The Labour government's expansion efforts underscore the aim of a gradual universalization of the ECEC system. However, a clear tension exists between these intentions and the chosen policy instruments: Sure Start and Children Centres target geographical areas rather than granting a right to every child, and thus actual access to ECEC services is not guaranteed. Nor do these Centres necessarily reach every child at risk or from a low-income background, since locations of disadvantage and individual circumstances of disadvantage do not neatly match. ${ }^{4}$ The very part-time nature of free preschool for three- to four-year-olds also hampers attempts to support the reconciliation of family and work. Most working parents need alternative care arrangements beyond the nursery school, and many are logistically not able to use preschools at all but rely on predominantly private and expensive day care. Parents in the UK spend on average a third of their income on childcare costs, the highest among OECD countries (OECD, 2007), and for many families the financial burden is even heavier. In London the average weekly cost for 25 hours of nursery care for a child under two is currently £118.54 (Daycare Trust, 2011). The affordability of childcare thus remains a significant problem for many families, in practice hindering many mothers of small children from entering the labour market (Ball/Vincent, 2005, p.561). Informal care remains the dominant form of extra-familial childcare; in the early 2000 s 70 per cent of employed mothers relied on informal childcare (Lewis, 2003, p.232). The quality of ECEC services is another problematic area. In nursery schools for three- to four-year-olds there are trained teachers, yet the children

${ }^{4}$ Tunstall and Lupton (2003) have even found that most poor children did not live in disadvantaged areas. 
are subjected to high teacher-to-pupil ratios and have to adapt to school education-oriented classroom settings. For day-care staff, training requirements as well as pay are minimal, and this leads to high rates of turnover in these settings and leaves the question open as to whether there is sufficient competence to implement the national early-years curricula. These tensions are expected to increase as the newly elected coalition government in 2010 has announced their intention to reduce the scope of public Sure Start Centres, providing mainly part-time preschool education, and a refocusing of childcare policy targeting disadvantaged children.

\section{Discussion: ECEC services between marketization and universalization}

Over the last twenty-years the Swedish and British ECEC systems have undergone fundamental changes with respect to the quantity of available places, underlying rationale, and governance structure. Do these changes also reflect general welfare-state trends towards increased marketization? The answer is both yes and no: market mechanisms have been introduced in both ECEC systems but only within certain dimensions and to varying degrees. At the same time, early-years provision has been universalized following a very different 'public-good' logic, again to varying degrees in the two countries, that has older roots than the recent market-drive in social-services reform.

In the UK during the 1980s and in Sweden somewhat later in the 1990s a new focus on private-service provision appeared in ECEC policy with the aim to increase parental choice, diversity, and efficiency in the system. Particularly in Sweden, the space for market processes has, however, remained limited. Strict fee regulations and public funding of ECEC services, whether public or private, make price competition impossible, and high quality standards concerning staff training, ECEC activities, and facilities curb profit margins even further. Some commentators have even pointed to tendencies towards self-exploitation among small private providers to keep their businesses running (Bergqvist \& Nyberg, 2001). Nor did marketization imply decreased state involvement: public funding for ECEC has remained high, among the highest in the OECD (2007). Furthermore, while the number of commercial providers has increased continuously, the expansion of public places was greater. The changes in Swedish early-years provision with respect to marketization were thus incremental and did not lead to the dismantling of the public ECEC system. Should the number of for-profit providers increase to a more substantial proportion, this could eventually challenge the public organization and underlying social-rights logic of Swedish ECEC services.

In the UK, the trends of marketization in ECEC provision were more pronounced. While the development of a childcare market for children of working parents was of a more unplanned nature during the 1970s, NPM ideas introduced under the Conservative government in the 1980s paved the way for the marketization of ECEC governance, which also occurred in other parts of the public sector at that time. It was, however, first under New Labour in the 1990s when the rise of social-investment discourse made ECEC service expansion part of an economically oriented policy agenda. ECEC services in this model play an important role for welfare-state sustainability and economic growth by bringing parents into employment, lifting families out of poverty, and by giving children a good educational foundation so that they become productive workers in an internationally competitive knowledge economy. Nevertheless, despite the strong preference for the market model, the UK government did not retreat from the scene. To the contrary, a pronounced 
increase in state involvement can be observed since the 1980s. On the one hand, the childcare market did not grow by itself (Lloyd, 2008), but service expansion had to be promoted by the state by means of various measures. Secondly, the state had to mitigate negative market effects with respect to availability, affordability, and quality via targeted measures, demand-side subsidies to parents - who nevertheless shouldered the bulk of childcare costs - and standards and inspection regimes. An unexpected side effect of the market approach has been the increase in state regulation and centralization, which is evident in the very detailed and prescriptive English preschool curriculum (DfCSF, 2008).

In Sweden, we find a contrary development since the 1990s with the decentralization of ECEC governance and the relaxing of state regulations. For example, the Swedish preschool curriculum is only a few pages long, comprising mainly mission statements and broad objectives (Lpfö, 1998). Indeed, many municipalities do not even set requirements for ECEC providers concerning staff-to-children ratios or the like (Skolverket, 2008). Yet these reforms cannot be associated with a 'free-market' logic because they were attempts to strengthen local self-administration. The state is still the central player, albeit with a much enhanced role for local governments. Marketization and decentralization have led to greater variations in the ECEC system, and have therewith challenged its universalism. Nevertheless, Swedish ECEC stands out as displaying a high degree of equality from an international perspective (OECD, 2006). This may be a result of the strong and longestablished normative underpinnings of a system that emphasizes 'public good' and the social-rights aspects of early-years services.

The most dominant trend in Sweden dating back to the 1970s has consequently been the universalization of early-years services that followed the concept of integrated 'educare' which combines the aims of supporting the reconciliation of family and work with children's early education. This model has not been abandoned but reinforced in recent years, with massive increases in public ECEC services and the extension of a statutory right to a place for all children aged one to six. The underlying logic since the 1970s has been the gradual expansion of citizenship rights, including women's rights to equal access to employment and children's rights to a good upbringing and equal educational opportunities (Naumann, 2006). Developments in this direction have also taken place in the UK, though much more recently and relatively modest in extent, with universal part-time preschool for three- to four-year-olds, and particularly with the broader orientation towards universal 'educare' in Children's Centres.

Some scholars have interpreted the limited nature of universal preschool education in the UK as an incoherent implementation of the governments' social-investment agenda, because it ensures neither education for all children nor adequate support for employed parents (Jenson \& Saint-Denis, 2006; Lewis, 2003). However, while limited implementation may hamper the yielding of expected returns, the 'social-investment' logic in itself does not lead to universal social rights. From an instrumental-investment orientation it might be neither economically nor politically sound to provide universal ECEC for all children: post-industrial societies are not only knowledge economies but display large low-skill and low-pay service sectors. Providing all children with good ECEC would raise expectations, and could potentially create political tensions and demands for social and economic change should the economy prove unable to provide adequate employment for all well-educated children. My point here is that the introduction of universal preschool education and universal Children's Centres were driven by a different older, social-rights 
logic. Claims around gender equality and children's well-being and education had been around for a long time in the UK, just as in Sweden, but without their transformation into policy. The social-investment discourse then opened the opportunities for feminists and children's rights advocates to influence ECEC policy and to broaden its remit in areas where they had been unsuccessful in the past (Wincott, 2006).

Also, in the Swedish case we could argue that 'social-investment' ideas created opportunities for ECEC services to develop, but long before the 1990s. The link between ECEC services and 'productivist' welfare-state goals (i.e., raising children to become productive citizen-workers) goes a long way back to conceptions of 'preventive social policy' that were constitutive of the Swedish welfare state in the 1930s (Myrdal, 1945). Swedish ECEC service expansion in the 1970s and 1990s was also motivated by the government's interest in increasing employment rates and state revenue (Naumann, 2006). The Swedish approach to social investment has, however, always been integrated with a redistributive-citizenship conception of service provision (see Esping-Andersen, 2002).

\section{Conclusion}

This examination of recent policy developments in the field of early-years services in Sweden and the UK has revealed that marketization is not the only trend common to such provisions in both countries. Another important driver for reform has been the extension of children's rights to early childhood education. Further developments include shifts in the relation between central and local governments in ECEC governance that cannot easily be attributed to either marketization or universalization trends. Thus, a general summation is that service-sector reforms are more complex than the controversy between 'state' and 'market' in policy debates may suggest. A second, more specific finding stands out: while both economic and rights-based ideas have shaped policy goals in Sweden and the UK, it matters which policy reforms came first. In Sweden, on the one hand, market mechanisms were introduced into a wellestablished, fairly universal public ECEC system, with limited effects on the overall system; in the UK, on the other hand, ideas about universal access to ECEC became prominent after a 'childcare market' had already been created, and the instruments chosen to support this market (i.e., demand-side subsidies) limited the possibility to expand public-service provision. Universal preschool access in the UK is thus of a rather limited nature. The tensions between political promises to 'invest in children', all children, and actual policy implementation may, however, produce pressures for further change towards a more universal model.

Central to this article, therefore, is the observation that policy developments in welfare states continue to be shaped by historical trajectories, but not in a steady and linear fashion; nor do they evolve neatly from one 'paradigm' or 'regime' to another, but may include the maturation of 'old' welfare-state promises alongside the exploration of new paths. An investigation of the interplay between different underlying logics and goals of policy reform and the resultant dynamics of change may be a fruitful focus for future research on the restructuring of welfare states. 


\section{References}

Antman, P. (1996). Barn och äldreomsorg i Tyskland och Sverige. Sverigedelen [Children and elderly care in Germany and Sweden: Swedish part]. Skriftserien Fakta/kunsaper 5, Stockholm.

Bahle, T., \& Pfenning, A. (2001). Angebotsformen und Trägerstrukturen sozialer Dienste im europäischen Vergleich [A Western European comparison of forms of offers and structures of social-support services], available at: http://ideas.repec.org/p/erp/mzesxx/p0013.hml (accessed April 13, 2010).

Ball, S., \& Vincent, C. (2005). The 'childcare champion'? New Labour, social justice and the childcare market. British Educational Research Journal, 31(5), 557-570. doi: $10.1080 / 01411920500240700$

Bergh, A. (2004). The universal welfare state: Theory and the case of Sweden. Political Studies, 52(4), 745-766. doi: 10.1111/j.1467-9248.2004.x

Bergqvist, C., \& Nyberg, A. (2001). Den svenska barnomsorgsmodellen - kontinuitet och förändring under 1990-talet [The Swedish child-care model: continuity and change during the 1990s]. In Statens Offentliga Utredningar, Välfärdstjänster $i$ omvandling [Welfare services in transition] (pp. 239-287). Stockholm: SOU 2001:52.

Blomqvist, P. (2004). The choice revolution: Privatization of Swedish welfare services in the 1990s. Social Policy \& Administration, 38(2), 139-155. doi: 10.1111/j.14679515.2004.00382.x

Brewer, M., Crawford, C., \& Dearden, L. (2005). Reforms to childcare policy. In R. Chote, C. Emmerson, D. Miles, \& Z. Olderfield (Eds.), Green Budget 2005 (pp. 146-174). London: Institute for Fiscal Studies.

Cohen, B., Moss, P., Petrie, P., \& Wallace, J. (2004). A new deal for children? Reforming education and care in England, Scotland, and Sweden. Bristol: The Policy Press.

Department for Children, Schools and Families (DfCSF) (2008). Statutory Framework for the Early Years Foundation Stage. London: DfCSF.

Department for Education and Skills (DfES) (1998). Meeting the childcare challenge. London: DfES.

Daycare Trust (2011). Tenth annual childcare cost survey, London.

Esping-Andersen, G. (2002). A child-centred social investment strategy. In G. EspingAndersen (Ed.), Why we need a new welfare state (pp. 26-67). Oxford: Oxford University Press.

Her Majesty Treasury (HMT) (2001). Tackling Child Poverty: Giving Every Child the Best Possible Start in Life. London: The Stationary Office.

Her Majesty Treasury (HMT) (2004). Choice for parents, the best start for children: $A$ ten year strategy for childcare. London: The Stationary Office.

Jenson, J., \& Saint-Martin, D. (2006). Building blocks for a new social architecture: the LEGO paradigm of an active society. Policy \& Politics, 34(3), 429-451. doi: $10.1332 / 030557306777695325$ 
Lewis, J. (2003). Developing early years childcare in England. 1997-2002: The choices for (working) mothers. Social Policy \& Administration, 37(3), 261-286. doi: $10.1111 / 1467-9515.00335$

Lloyd, E. (2008). The interface between childcare, family support and child poverty strategies under new labour: Tensions and contradictions. Social Policy \& Society, 7(4), 479-494. doi:10.1017/1474746408004442

Lpfö (1998). Läroplan för förskolan [Curriculum for preschool], Stockholm: Skolverket.

Myrdal, A.(1945). Nation and family: the Swedish experiment in democratic family and population policy. Cambridge: MIT Press.

Naumann, I., \& Crouch, C. (forthcoming). Between marketisation and participation. Changing school governance in England and Sweden.

Naumann, I. (2006). Childcare politics in the West German and Swedish welfare states from the 1950s to the 1970s. Unpubl. Doctoral Thesis, Florence: European University Institute.

Organisation for Economic Co-operation and Development (OECD). (2005). Babies and bosses: United Kingdom. Paris: OECD.

Organisation for Economic Co-operation and Development (OECD). (2006). Starting strong II: Early childhood education and care. Paris: OECD.

Organisation for Economic Co-operation and Development (OECD). (2007). Babies and bosses: Reconciling work and family life: a synthesis of findings for OECD countries. Paris: OECD.

Penn, H. (2009). Public and private: the history of early education and care institutions in the United Kingdom. In K. Scheiwe \& H. Willekens. (Eds.), Child care and preschool development in Europe (pp. 105-125). Basingstoke: Palgrave.

Penn, H. (2010). International perspectives on quality and mixed economies of childcare. National Institute Economic Review, 207, 83-89. doi:10.1177/0027950109103687

Plantenga, J., Remery, C., Siegel, M., \& Sementini, L. (2008). Childcare services in 25 European Union member states: The Barcelona targets revisited. In A. Leira \& C. Saraceno (Eds.), Childhood: Changing contexts (pp. 27-53). Comparative Social Research, 25. Bingley: Emerald JAI Press.

Pollit, C., \& Bouckaert, G (2000). Public management reform: A comparative analysis. Oxford: Oxford University Press.

Randall, V. (2002). Childcare in Britain or how do you restructure nothing? In S. Michel \& R. Mahon (Eds.), Child care at the crossroads: Gender and welfare state restructuring (pp.219-238). New York: Routledge.

Ruggie, M. (1984). The state and working women: a comparative study of Britain and Sweden. Princeton N.J.: Princeton University Press.

Sainsbury, D. (1991). Analysing welfare state variations: the merits and limitations of models based on the residual-institutional distinction. Scandinavian Political Studies, 14(1), 1-30. doi: 10.1111/j.1467-9477.1991.tb00403.x 
Skolverket (2007). Fem år med maxtaxa [Five years with full fees]. Rapport 294, Stockholm.

Skolverket (2008). Tio år efter förskolereformen. Nationell utvärdering av förskolan [Ten years after the preschool reform: national evaluation of preschools]. Rapport 318, Stockholm.

Smith, T. (2007). Early years services in Britain 1997-2007: a quiet revolution? Journal of Children's Services, 2(2), 26-38.

Sveriges Officiella Statistik (SOS). (2010). Förskola i siffror [The preschool in numbers]. Stockholm.

Statens Offentliga Utredningar (SOU). (1972). Förskolan. Betänkande från 1968 års barnstugeutredning [Preschool: report on the children's day-care study of 1968]. SOU 1972:26, SOU 1972:27, Stockolm: Liber Förlag.

Strandbrink, P., \& Pestoff, V. (2006). Small-scale welfare on a large scale: social cohesion and the politics of Swedish childcare. Stockholm: Södertörns Högskola.

Taylor-Gooby, P. (2008). The new welfare settlement in Europe. European Societies, 10(1), 3-24. doi: 10.1080/09571260701526964

Tunstall, R., \& Lupton, C. (2003). Is targeting deprived areas an effective means to reach poor people? Assessment of the rationale for area-based funding programmes. CASE Paper 70, Centre for Analysis of Social Exclusion, London: London School of Economics.

United Nations (UN). (1989). Convention on the rights of the child, Geneva: UN.

Wincott, D. (2006). Paradoxes of New Labour social policy: toward universal child care in Europe's 'most liberal' welfare regime? Social Politics, 13(2), 286-312. doi: 10.1093/sp/jxj011 